\title{
Study of Carbon Value of the Allotment of Former Coal Mining Land of PT Samantaka Batubara for Sustainable Mining Environment
}

\author{
Restu Juniah $^{1}$ \\ ${ }^{1}$ Sriwijaya University, Indonesia \\ Correspondence: Restu Juniah, Sriwijaya University, Indonesia. E-mail: restujuniah@ft.unsri.ac.id \\ Received: February 28, 2018 \\ Accepted: May 17, $2018 \quad$ Online Published: July 29, 2018 \\ doi:10.5539/jsd.v11n4p213 \\ URL: https://doi.org/10.5539/jsd.v11n4p213
}

\begin{abstract}
Sustainable environment is a hope for the sustainability of a civilization, because environmental damage can destroy civilization. Mining commodities needed by humans to build civilization and the fulfillment of the necessities of life such as houses, high rise buildings, motor vehicles, mobile phones, electronic equipment, home appliances, office equipment, and others. Mining activities are conducted to obtain mining commodities. Mining companies during the life of the mine are obliged to keep the mining environment sustainable, and entirely entitled to determine its former mining land. Revegetation activities on former coal mines can provide external benefits of carbon values. Research conducted by survey with quantitative method aims to provide an economic assessment of the carbon value of former coal mine land of PT Samantaka Batubara for rubber plantations. The research finds that the carbon value of former mining land of PT Samantaka Batubara for rubber plantation can keep the mining environment sustainable. The economic valuations undertaken to determine the value of carbon use the equations found in this study developed from previous studies. The results of the study found the value of carbon benefits on mining land of PT Samantaka coal worth IDR 1,014,329,829, - or USD 75,770 for the range of restoration of ex-mining land in 2017-2022 PV 2017. The results are expected to be useful and can be used by stakeholders, academics, researchers, practitioners and associations of mining, and the environment.
\end{abstract}

Keywords: carbon value, allotment of former coal mining land, sustainable mining environment

\section{Introduction}

Government Regulation of Republic of Indonesia No. 23 year 2010 concerning the Implementation of Mineral and Coal Mining Business Activities, asserts that the utilization and management of natural resources must contribute to the sustainability of human life and other living creatures, and be implemented wisely on the basis of ecological principles. Integrating the environment in mining operations can make the mining environment economically, socially and ecologically sustainable. This is in line with Kokko et.al (2015) research results, that the objectives and equilibrium tools of economic, social and environmental pillars in the mining sector are sustainable mining. In order to protect the environment then the Environmental regulatory function is one of the important things needed for the balancer.

The integration of the environment in any activity or business undertaken in the territory of the Republic of Indonesia has been in existence since the enactment of Law Number 32 Year 2009 on Environmental Protection, and Government Regulation Number 27 of 2010 on Environmental Permits. The economic assessment which is an integral part of the integration of the environment is specifically regulated in Government Regulation No. 46 of 2017 on Environmental Instruments (enacted on 27 November 2017). Based on this Government Regulation, it is important to conduct and provide an economic assessment for the preservation of environmental functions. Recovery of ecosystem functions is an important first step to be taken after the end of mining activities. This is because ecologically diverse forests can be drastically disrupted by coal mining activities (Dallaire, 2015).

The environment has a primary function as a provider of raw materials (natural resources), in addition to the function of carbon assimilator and aesthetic value.

Thus, natural resources such as renewable resources such as forest plants, and unrenewable resources such as coal must be maintained and maintained so that the environment does not lose its function and remain sustainable. Therefore, environmentally sound development becomes an important requirement for every nation 
and country that wants the preservation of natural resources and the preservation of environmental function (Juniah, 2017).

The availability of natural resources of coal in Indonesia is mostly located in forest areas and its utilization is done by open pit. This utilization provides direct economic and social benefits. Such benefits are the sources of state revenues and foreign exchange earners, as raw material producers for industry, infrastructure and facilities development, employment providers, employment absorption. Indirect benefits (external benefits) obtained through revegetation activities on ex-mining land include carbon value. The concept of externalities is a fundamental foundation of the analysis in this study. The concept of externalities is applied to analyze the value of external benefits.

The coal mining business activities openly in the forest area, on the one hand, provide economic and social benefits but on the other hand create environmental impacts, which can disrupt the preservation of environmental functions (Juniah, 2017). This is caused by landscape change, which starts from the activities of land clearing, stripping, transporting and stockpiling of soil shoots, soil and mining commodities (minerals, coal or rocks). The impacts that arise are difficult to ignore just because the impact that arises not only in the primary but also secondary.

Derivative effects such as decreasing air quality have an impact on the health of the community, and will eventually result in external costs to public health (Juniah, 2013). Decrease in air quality occurs due to loss of trees or plants that become carbon uptake media. Revegetation activities can restore environmental function and services lost due to coal mining activities.

How to mine while maintaining the preservation of environmental functions is crucial to the sustainable mining environment both economically, socially and ecologically. This is in line with the concept of sustainable development and good mining practice.

Reducing the use of petroleum fuels whose deposits are depleted, is one of which can be done with the use of coal as an alternative energy source. Calorific coal as a source of heat can be utilized for various interests such as industry, household and electric power generation. Policies made by the central and local governments in Riau Province to support conducive conditions for investors are the driving factors for the establishment of mining business entities, including PT. Samantaka Batubara.

PT. Samantaka Batubara will conduct reclamation activities consistently and continuously, and has a clear plan for the allotment of its former mining land (PT Samantaka, 2017). This is done in order to improve or arrange the use of disturbed land due to coal mining, so that it can function and efficient in accordance with its purpose in order to preserve the function of the environment. This is realized by PT Samantaka Batubara, because mining activities have the potential to change the landscape, so it is necessary to utilize the land in the former mining activities to function in accordance with its designation in accordance with the prevailing laws and regulations.

The obligation to make the allotment of former mining land plan is regulated in Government Regulation No. 78 of 2010 on "Reclamation and Former mine", Ministerial Regulation No. 7 year 2014 on the Implementation of Reclamation and Post-Mining Plan on Mineral and Coal Mining Business Activities. This research is conducted in order to preserve the function of the environment, and as the implementation of Government Regulation of the Republic of Indonesia Number 46 Year 2017.

\section{Material Studied}

This research was conducted in PT. Samantaka Batubara. Research location of Coal Mining Business License PT. Samantaka Batubara in Peranap Subdistrict (Pauh Ranap \& Gumanti Village), Batang Peranap Subdistrict (Punti Kayu Village), Rakit Kulim Subdistrict (Talang Durian Cacar Village) Indragiri Hulu Province Riau Province is located in the southeast of Pekanbaru City. The location of the study is shown as in Figure 1. 


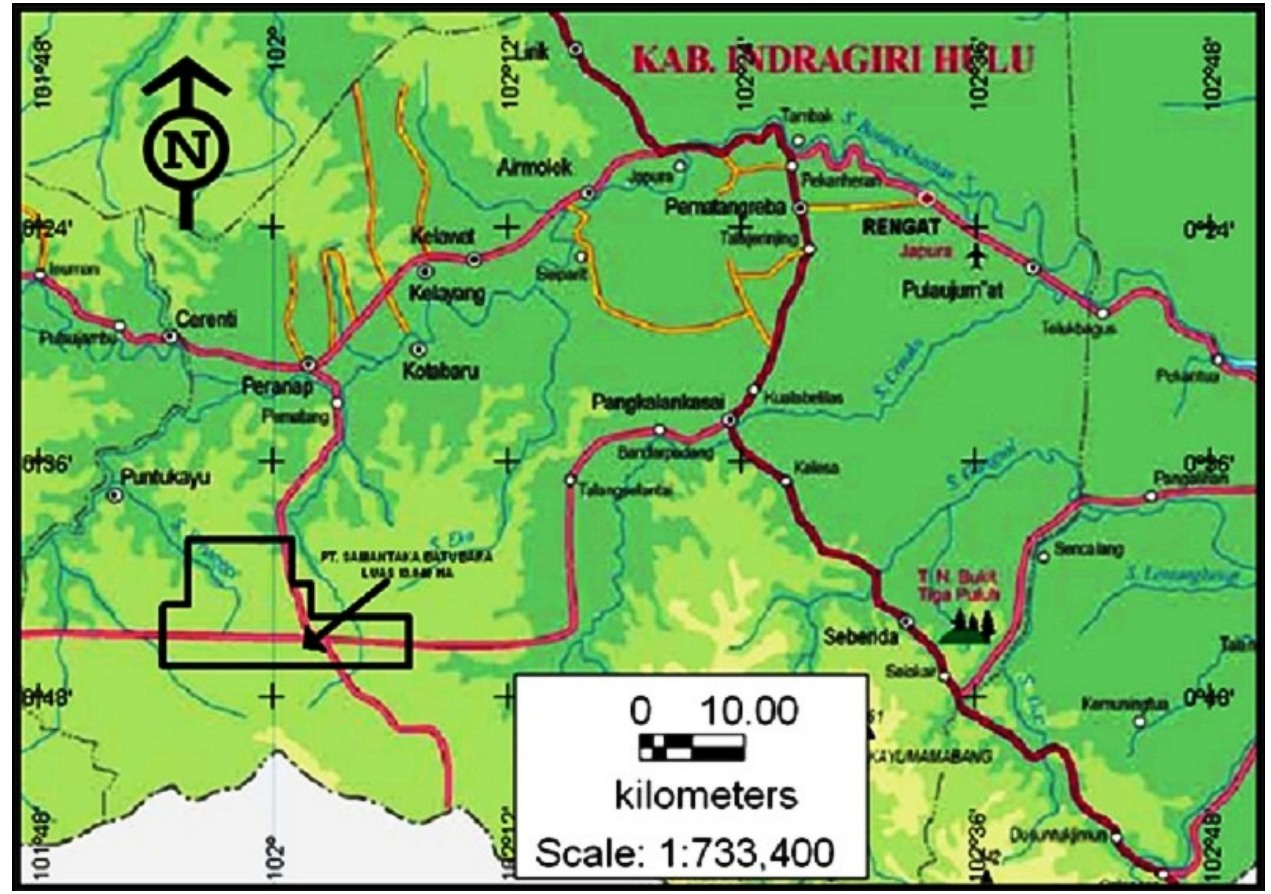

Figure 1. Map Location of PT. Samantaka Batubara

Source: Juniah, 2017

\section{Area Descriptions}

Delivery of the region can be reached by road from Pekanbaru City towards Peranap through the East Cross Road Sumatra with a distance of approximately $200 \mathrm{Km}$ or travel using Four Wheel vehicle with paved road conditions for approximately 4 hours.

\section{Methods}

This research is based on the type of survey research, including conducting direct observation to the location of coal mining business permit which becomes the object of research. Selection of research location by purposive sampling, in accordance with the purpose that cooled by the researcher with consideration: 1) PT Samantaka Batubara as one of coal mining company which has License of Lending of Forest Area (IPPKH) from Ministry of Environment and Forestry Republic of Indonesia, ex-mine in accordance with the regulations applicable in the Ministry of Environment and Forestry of the Republic of Indonesia; 2) PT Samantaka Batubara as embodied in the Post-Mining Plan document will enter post-mining in 2022 so that this study considers it necessary to conduct economic valuation of the former mining land for rubber plantations.

Quantitative methods are used to quantify carbon values using the equations developed from previous studies (Rahmaputri, 2014), and Juniah (2016). Data collection is done through collecting data both in primary data, and secondary data. Primary data obtained by doing direct observation, and from data processing. Secondary data by doing literature study search, and officially. Descriptive analysis is used to describe how conditions in former mining land of PT Samantaka Batubara, and its allotment for the return of mining environmental function in a sustainable manner.

\section{Results and Discussion}

\subsection{Mining Activities of PT Samantaka Batubara}

Stages of mining activities conducted in coal mining in Indonesia are generally the same, both in small and in large scale coal mining, such as coal mining PT Bukit Asam in South Sumatra Province, Coal Mining PT Kaltim Prima Coal in East Kalimantan Province, Coal Mining PT Adaro Indonesia in South Kalimantan Province. Similarly, the stages of coal mining activities in PT Samantaka Batubara.

The mining method used in general is also the same in the open pit. The mining method implemented at PT Samantaka Batubara is a conventional open pit method using a combination of backhoe and dump truck 
equipment as well as bulldozers as main mining and graders for road maintenance. Coal mining activities at PT Samantaka Batubara are shown in Figure 2.

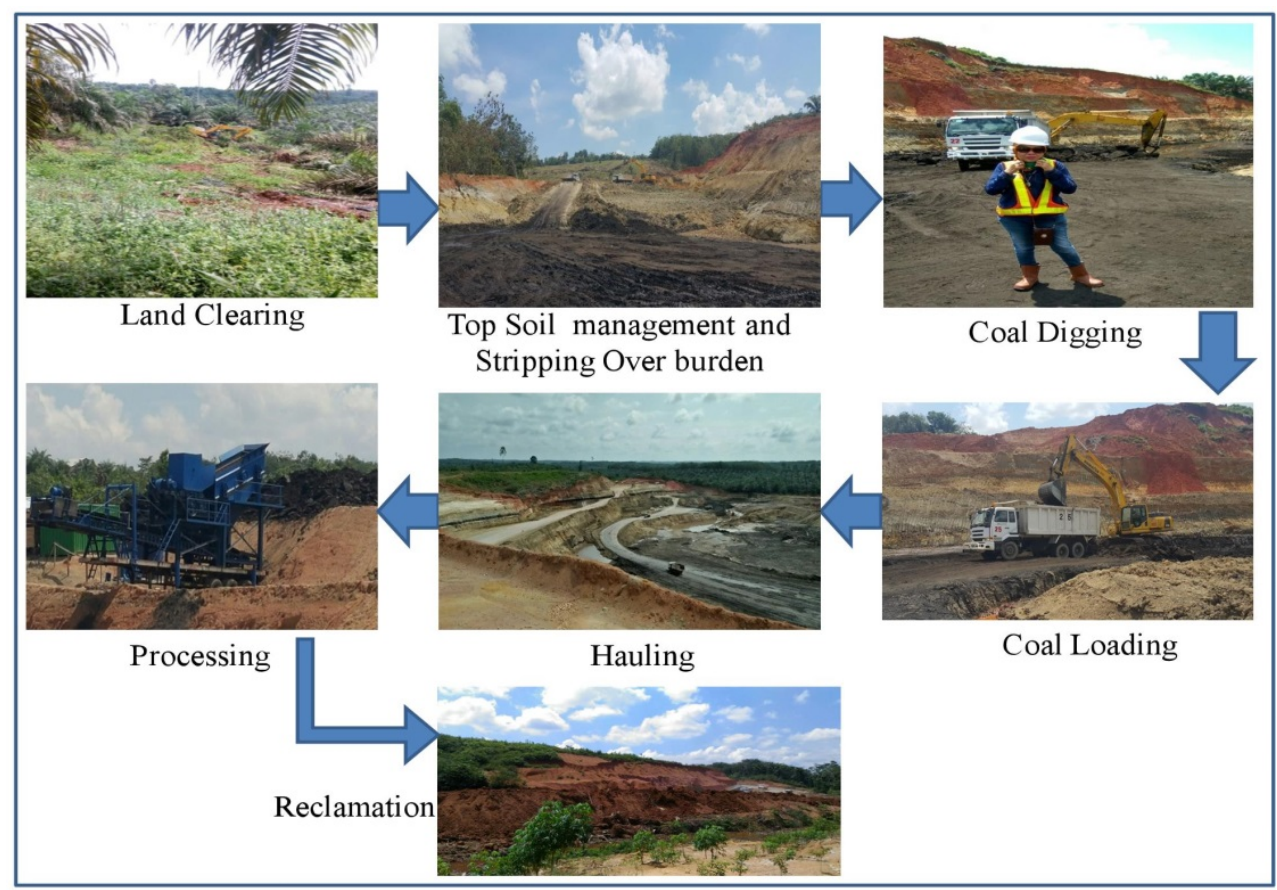

Figure 2. Coal Mining Activities at PT Samantaka Batubara

Source: Research Results, 2017

Mining operations consisting of hoisting, loading and hauling, and preceded by land clearing activities are carried out simultaneously which means that, while land clearing activities are continuing, and after extensive clearance of the land is sufficiently large and safe for the work site of digging tools, can start immediately. Stages of coal mining activities in PT Samantaka Batubara as follows:

1) Land clearing;

2) Top soil management and stripping over burden;

3) Digging and loading;

4) Hauling;

5) Processing;

6) Reclamation.

Stages of coal mining above explain as:

\section{Land Clearing}

Plants located in the location of coal mining activities of PT Samantaka Batubara generally in the form of shrubs, rubber, palm, jabon (neolamarckia cadamba), rengas (gluta renghas), meranti (shorea), pule (alstonia sholaris), waru (hibiscus tiliaceus), banana, areca nut and shrubs.

Land clearing using bulldozers is equivalent to Komatsu D 85, equipped with wirerope to pull trees. Trees of relatively large size were cut with chainsaws. The trees are then collected at designated locations to facilitate inventory activities in the context of compensation to the state or further utilization.

\section{Top Soil Management}

Top soil is necessary for reclamation activities (rehabilitation of ex-mining land). The activity of topsoil management at PT Samantaka Batubara is done as follows:

1) Excavation and or collecting of shoots;

2) Transportation to the location of soil shoot preservation; 


\section{3) Spreading of shoots at reclamation sites.}

Excavation and loading of shoots is conducted by excavator that is equivalent to Komatsu PC 400, whereas in a location that is difficult to reach by excavator, top soil is collected in advance by the Komatsu D 85 equivalent bulldozer. The top soil stripping operation is performed after the cleaning operation is completed to the layer of soil that contains a lot of organic materials weathering, which is very good for soil fertility. This fertile layer of soil is peeled off by using a blade of bulldozer. Bulldozer operator is peeling the fertile soil near the bulldozer operating area. Thus in the mining area there will be a fertile landfill location which in turn will be used for the reclamation of former mining land. This top soil removal work uses excavator as a loader, and dump truck as a conveyance.

The peeling of shoot thickness is ranged from 0.1 to 0.3 meter. Excavation activities and stripping of shoot soil can be done more deeply if it is still classified as soil shoots that still contain organic nutrients. This thick layer is often found in valley and basin areas. Top soil stripping results can be distributed directly to ex-mining areas that have been reclaimed or stored in a place (bank top soil). This temporary stockpile is in a flat and high enough area and there is no erosion and is marked with clues. It is expected to keep the fertility and soil quality can be maintained. Top Soil Stock's Area is in outpit with an area of 2.80 ha which is used to temporarily store top soil from stripping soil until it is used again for reclamation purposes (Document of Reclamation Plan of PT Samantaka Batubara, 2017).

\section{Soil Closure Landfill}

The series of activities in stripping of soil cover are as follows :

1) Loosening;

2) Digging and loading;

3) Hauling;

4) Dumping land cover (dumping).

The operation of excavation of overburden and interburden is done by using excavator and assisted by bulldozer. Excavator can directly conduct excavation and loading onto a dump truck for weak to medium material. Bulldozer will help to raise for the material rather hard, before excavated and loaded by excavators. The use of ripper in bulldozers will be tailored to the needs of the operation of the material within the planned excavation bars, the excavator operator will establish a bench, assisted by the bulldozer operator. Articlate Dump truck with a capacity of 45 tons as a means of transport is used to transport the land cover from the mining area to the dumping area (dumping area). Dumping areas are in the area of the valley or flat morphology of the nearest location or at the back filling location. This cover is arranged in stages using a dozer.

\section{Excavation, Loading and Hauling of coal}

Activities at this stage to dig and load coal. The coal excavation and loading activities are carried out after stripping. The equipment used is Komatsu PC 300 Excavator with bucket equipped with cutting edge. The next stage is Coal Getting with Komatsu PC 300 and loaded into the port by using the Dump Truck of Nissan CWB 45. Coal transport of PT. Samantaka Coal is done from the mine to the processing facility using a dump truck. This activity is done after the coal is dug and loaded into the dump truck tool.

\section{Processing}

Processing activities are the last stage in coal production operations. Coal coming from the mining front can be sold if it has been qualified or has been in accordance with market and user demand rather than coal. Coal as fuel can be used for electricity generation needs, cement plant needs, smelter needs and others. Processing activities conducted at PT Samantaka Batubara aims to meet market demand and users of coal PT Samantaka Batubara. Processing activities carried out in the form of reducing the size of coal in accordance with market demand and users of coal PT Samantaka Batubara. Primary market and coal users of PT Samantaka Batubara for coal-fired power generation activities. This is considering the coal of PT Samantaka Batubara belongs to the low rank coal group (Low Rank Coal) ranging from 4300-5400 K kal / kg (ADB) (Document Feasibility Study of PT Samantaka, 2011).

Coal processing activities at PT Samantaka Batubara are carried out by the following processes:

1) Do size reduction through crushing activity.

2) Perform classification through screening

3) Conducting coal deposits in stockpiling. 


\section{Reclamation of Former Mining Area}

Land is disturbed due to mining conducted by PT. Samantaka Coal as far as possible will be reclaimed and revegetated. The land to be reclaimed is Former Mine, Landfill/ Abandoned Mine Closure, Sediment Pond Mine Road, and Other Support Facilities. The techniques and methods and equipment used in the following reclamation activities (Document of Reclamation Plan of PT Samantaka Batubara, 2017):

1) Efforts made to achieve reclamation goals one of which is the management of shoots. The company in this case stripping the top soil (collapsed soil layer) collected in a certain area and marked later used as the top layer cover as the main nutrient source in the revegetation process.

2) Mining is done by drainage system and slope planning in accordance with the technical and mechanical properties of the soil. The slopes that are formed are made terraces often in addition to maintaining the stability of the slope technically, also cursed as the placement of revegetation crops. This is when overburden is still not sufficient to cover the average ex-mining area.

3) Reclamation work is done as soon as possible in the areas of excavated mine. The work undertaken includes:

a. Arrangement of land on mined excavations

b. Minimize the angle of inclination with the equalization of the soil in mining excavations and slope grid fireplaces. Comparison The smoothed level is made at least 3:1 where the erosion rate and success rate of planting are sufficient. Making drainage at the mine level and fireplace ladder forming a small tilt angle can offset this sufficient level of erosion. Preparation of holes in ladders filled with top soil mixtures and coverings, compost, lime, artificial fertilizers and livestock manure are carried out for replanting on former traces already used.

c. Arrangement of soil in waste dump area

Reclamation at this location consists of land preparation and replanting. Preparation activities carried out for the equitable distribution of land surface. The exhaust is still a pile or pile at the discharge site flattened, and after the soil condition is flat it can be made hole for tertiary tree plant. Mixture of topsoil and soil cover, compost/livestock dung and lime is then included in the plant hole. This mixture is allowed for 2-3 days to allow the heat generated from the lime reaction with the soil to be removed. Plants can be planted after the land and holes are ready. The creepers with spacing $(4 \times 4)$ m were planted on the site of mine waste land. Wastewater land should be covered with a cover made of woven bamboo or rumbia roof leaves that serves to control erosion. This activity is done during the growth of cover crops. Fulfilling the needs of plant seeds used for rehabilitation taken from both the nursery itself and also works with village communities around the mine site. Cover crops with the type of colopogonium among the staple crops are grown to accelerate the fertility of the land and the improvement of micro climates at the location of the coal mining business permit PT Samantaka Batubara.

d. Monitoring of ex-mining slopes is routine. This is important because the condition of the former slope of coal mining for the activities of revegetation and reclamation must remain stable at former coal mining activities.

e. The community is given understanding not to cut trees, especially on the vegetation that is maintained. Understanding is given in the form of appeals and bulletin boards.

f. Reclamation activities carried out by involving the community and in cooperation with the Forestry Office of Indragiri Hulu Regency.

Reclamation activities using Backfilling method is applied by PT Samantaka Batubara by closing the area which is not disturbed by mining activities. Ground cover at the initial stage is placed in the disposal (mining area) is then used for backfilling in the pit. The top soil lies to the north of the mining activities and is dispersed at the pit openings (mine-finished areas). Common problems in revegetation of mining land in the form of physical, chemical (nutrient and toxicity) and soil biology. Soil chemical problems are related to soil reaction $(\mathrm{pH})$, nutrient deficiency, and mineral toxicity. This is because the condition of the land that has been done coal mining activities is no longer like the condition of the initial hue before the existence of coal mining activities. The addition of lime is done to overcome low $\mathrm{pH}$. Biological issues are such as the absence of vegetation cover and the absence of potential microorganisms. This is overcome by improving soil conditions, choosing tree species, and utilizing rhizobium or mikroriza. Related research on soil and biology for plant activities at project footprint has been conducted by Kusmana et. al, (2013). Kusmana's research finds that the character of the soil in coal mining of PT Arutmin Indonesia Site Batulicin South Kalimantan Province used as a test medium has an effect on plant growth 
causing stunt in the sengon (albizia chinensis) and acacia plants used.

The Cover Crops plants, and staple crops such as rubber plants are the plants selected for reclamation activities of PT. Samantaka Batubara. The selection of such crops is based on several considerations such as land suitability, suitability of possible growth and beneficial principle, and as a productive local plant with a large population and can grow well around the area of PT samantaka Batubara Mining Business License.

The use of superior seeds to obtain high productivity and stand quality is conducted at the seedling stage, in addition to the use of planting media, fertilization and prevention of pests and diseases. Fertilization is done to care plants since in the nursery so that seeds can grow and develop well. Planting pattern is arranged based on the rules and the results of existing research, namely by considering the aspects of soil and water conservation. The pattern of the plant is set with spacing $4 \mathrm{~m} \times 4 \mathrm{~m}$.

\subsection{Land Allotment at Former Mining Area of PT Samantaka Batubara}

Based on prevailing laws and regulations in the territory of the Republic of Indonesia, it is mandatory for companies engaged in the mineral and coal mining sector to plan ex-mining land after the end of part or all of the mining business activities conducted. Changes in landscape elements such as topography, cover vegetation, hydrological patterns, soil structure damage, etc. due to the use of open-pit methods can complicate the reclamation process. This condition can be overcome with the appropriate approach and technology. Approach and technology used will be different depending on the nature of the disturbance that occurred and also its use after the reclamation process. (Dariah et al, 2010).

Coal mining activities at the end of its mining activities will leave the former mining site. Land left behind can be void (pond former mine), or empty land (non void). Ex-coal mine land (void or non void) can be utilized for various utilization or benefit. Ex-void fields of void-shaped coal can be earmarked for freshwater fishery cultivation, for water tourism, source of drinking water (Juniah, 2013). Ex-mining land in form of vacant land can be reserved for plantations, livestock, forestry, and others. This is shown from the results of previous research and researcher conducted. The former open pit fields in west virginia are utilized to produce bioenergy crops such as switchgrass (Panicum virgatum) and Miscanthus (Miscanthus x giganteus) which is a seasonal summer grass having summer. High biomass production potentials are shared by both species, where the Terms grow both these plants on low soil fertility. (Scagline et.al, 2015).

Former coal mining land of PT Kitadin in East Kalimantan Province can be utilized as sustainable beef cattle breeding business (Daru et al., 2016). The former coal mine is suitable for rubber and palm oil plantation Syafrianto (2016). Mashud \& Manaroinsong (2014) former coal mine is suitable for sago plantation with balance fertilizer to be done on former coal mine land of PT. Kaltim Prima Coal (KPC) in East Kalimantan Province. Developing ex-mining areas for arboretum by conserving water, soil, and biodiversity especially local crop species (Yuniawatiningtyas, 2014). PT Adaro Indonesia (2012) in the province of South Kalimantan, in its former mining plans will utilize former mine land for lakes, irrigation, clean water, electricity, fishery programs, agriculture, livestock and plantation. Utilization of ex-mining land for plantation crops, cultivation of seasonal crops including paddy, and cocoa plants (Dariah et al, 2010). Hidayanto et al. Found that the former coal mining area in Kutai Kertanegara Regency at East Kalimantan Province can be developed for rice crops with a special management system or so-called Integrated Crops Land Management (ICLM). This system combines the use of organic materials, biological fertilizers and inorganic fertilizers. Towuti rice productivity with special management, about 6.6 tons/ha. Ex-mining land can also be used for sweet corn (Margaretta 2010) and jabon (neolamarckia cadamba) (Tamin, 2016). PT Nan Riang's former coal mine in Batanghari Regency of Jambi Province has been planted with jabon trees (Juniah et.al, 2012). The extraction of former mining land in several mines in Indonesia is shown at Figure 3. 


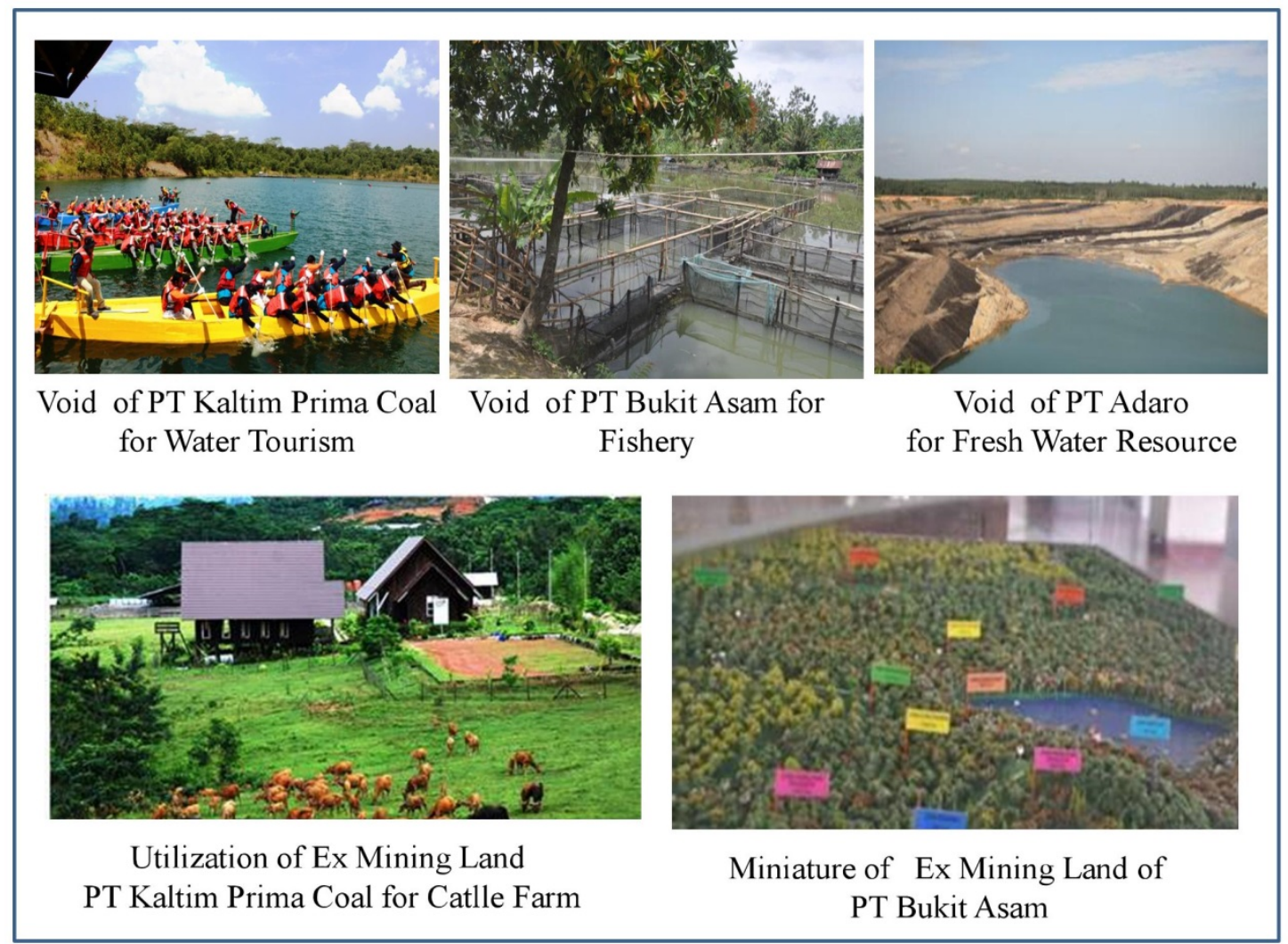

Figure 3. Ex mining land utilization in some mining companies in Indonesia

Source: Juniah, 2013; PT KPC, 2016

Based on the picture above shows that the former mining land, both in the form of voids and non voids have been used for various utilizations. PT Kaltim Prima Coal is utilized for Integrated Cow Ranch (PESAT) and void mine utilized for water tourism, for freshwater fishery cultivation (PT KPC, 2016). PT Bukit Asam utilizes voids for freshwater aquaculture, and ex-mining land for Smallholder Plantation (TAHURA), and PT Adaro utilizes voids for raw water sources using Water Treatment Plant 300 technology. (Juniah, 2013)

The purpose of the activities on ex-mining land is the restoration of environmental function in accordance with its designation. This is because the environment has a function as a provider of raw materials (natural resources), as a carbon assimilator and aesthetic value so that the environment does not lose its function and the survival of human life now, and future generations can be maintained and sustained (Juniah, 2017). The wise and environmentally sound utilization and management of natural resources becomes an essential requirement for every nation, country and party that wants the sustainability of natural resources. Rehabilitation is undertaken to restore areas or natural resources that are affected by mining activities to safe and productive conditions. The final condition of rehabilitation is expected to be as before it is mined or other conditions agreed upon. Based on this, PT. Samantaka Batubara is committed to maximizing ex-mining land use by managing the ex-mining physical environment. It is hoped this will provide sustainable benefits for companies and communities living around the mine, as well as the mining environment. Based on the results of public consultations and environmental impact analysis documents of PT Samantaka, and licensing owned (License to Use Forest Area), the former mining land of PT. Samantaka Coal is entirely for rubber plantation with area of $101.1 \mathrm{Ha}$ or $100 \%$ of the total mining area (PT Samantaka, 2017). The same allotment on former coal mines in West Virginia (Dallaire et. al, 2015), and former PT Asia Multi Investama coal mine in Tebo Jambi (Apriliana, 2016). The former coal mine in West Virginia was reclaimed for rubber plantation and PT Asia Multi Investama in Tebo Jambi Regency based on land suitability analysis.

The former mining location of PT Samantaka Batubara consists of former pit land, waste, mine road, settling pond, supporting facility and stock pile The percentage of ex-mining area disturbed by coal mining operations of PT Samantaka Batubara to mine closure in 2022 is presented in Figure 4. 


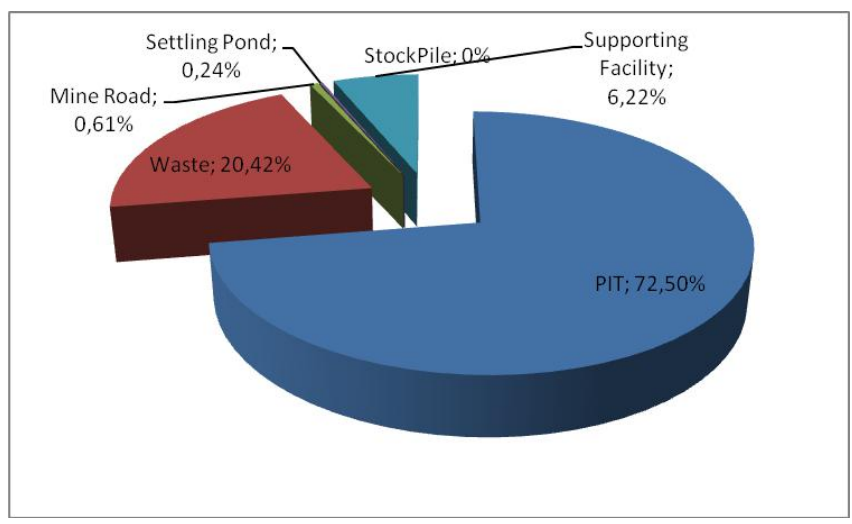

Figure 4. Presentage of land area of ex coal Mining of PT Samantaka Batubara

Source: Data edited, 2017

Based on Figure 4 above shows that PIT is the largest percentage left at the end of mining activities of PT Samantaka coal mining land that is $72.50 \%$ (73.3 ha) of the total land of 101.1 ha. The largest area to the next smallest is $20.42 \%$ (20.64 ha), supporting facility $6.22 \%$ (6.29 ha), mine road $0.61 \%$ ( $0.62 \mathrm{ha}$ ), settling pond $0.24 \%$ (0.24 ha).

Ex-mining land will be stockpiled with overburden. The overburden volume required to reforest this disturbed land to in pit dump 15,933,134 $\mathrm{Bcm}$ and out 1,600,000 $\mathrm{Bcm}$ of pit dump so that the required overall overburden is $17,533.134 \mathrm{Bcm}$. Top soil required as much as $1.011 .000 \mathrm{Bcm}$.

Coal excavation at the beginning of the activities of 2013 to February 2017, has not been done. PT Samantaka in this period just doing the digging and stockpiling of overburden. Overburden material excavated as much as $2,400.00 \mathrm{Bcm}$, and as much as $1.600 .000 \mathrm{Bcm}$ stockpiled to disposal to be the location of coal stockpile and the rest as much as $800,000 \mathrm{Bcm}$ directly in in pit dump. Thus at the end of mining activities (year 2022) the area will be stockpiled in stockpile of 0.00 ha. New coal excavations were conducted in March 2017.

The land area of PT Samantaka Batubara's former mine until 2022 is shown in Figure 5, and the Percentage of Land Used Mine of PT Samantaka Batubara Until Year 2022 is shown Figure 6.

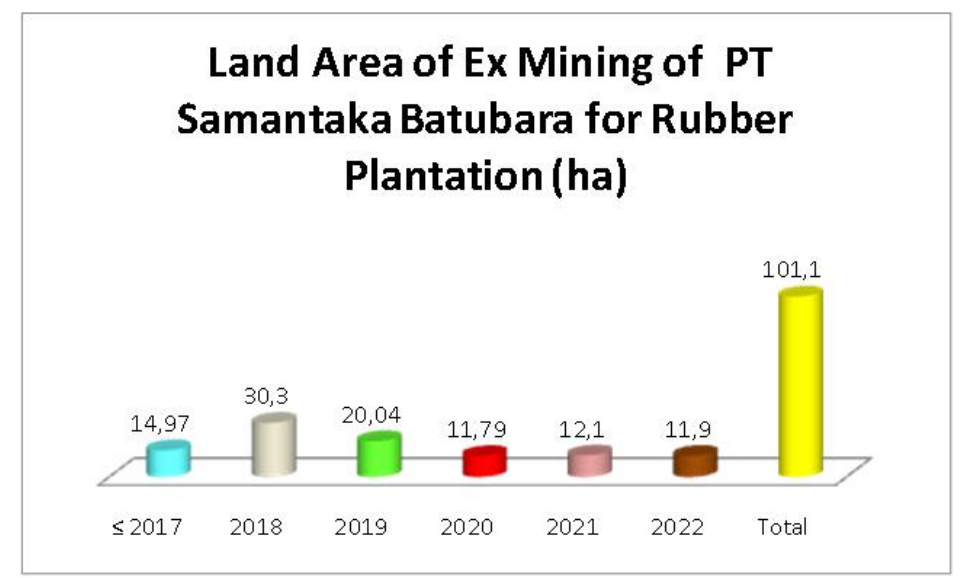

Figure 5. Land area of ex mining of PT Samantaka Batubara until 2022 


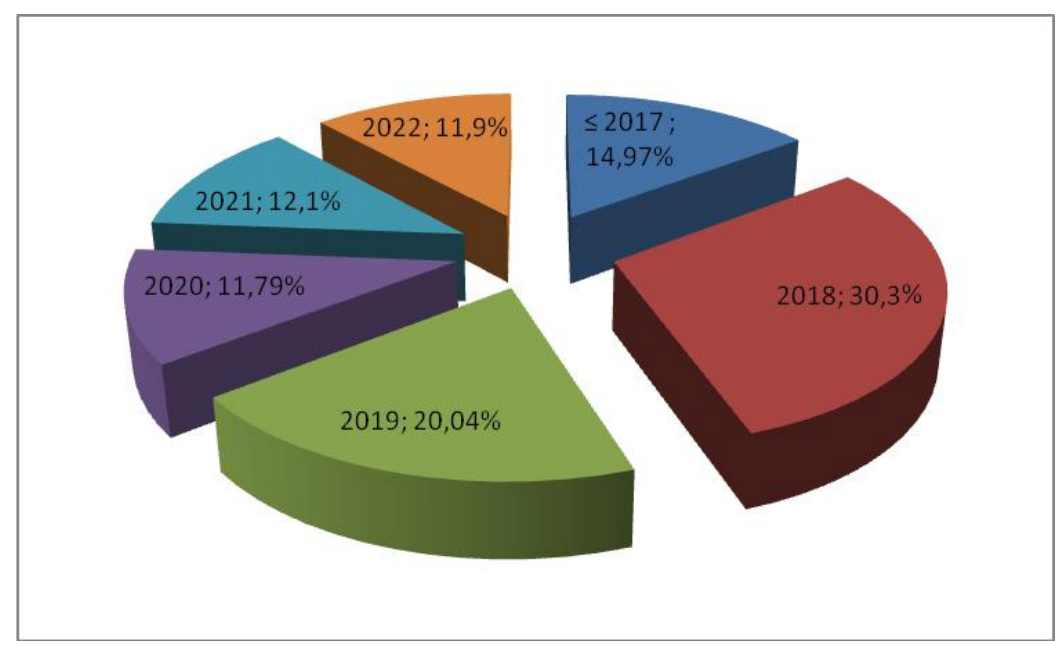

Figure 6. Persentage of Land Area of Ex Coal Mining of PT Samantaka Batubara until year 2022

Source: Data edited, 2017

Based on Figures 5 and 6, it is seen that in 2018 it is the former mining area with the largest percentage and area of PT Samantaka Batubara for rubber plantation of $30.3 \mathrm{ha}(30.3 \%)$. The smallest area of 2020 was 11.79 ha (11.79\%); the area in 2019 is 20,44 ha $(20,04 \%)$ for 14,97 ha $(14,97 \%)$ until 2017 respectively; year 2021 covering 12.1 ha $(12.1 \%)$, and year 2022 of 11.9 ha $(11.9 \%)$.

\subsection{Economy Valuation of Carbon Absorption of Former Mine Land of PT Samantaka Batubara}

Rubber plants aside as plantation crops, is also one of the forest plants. According to Togi \& Sahuri (2014). Rubber plants as plantation crops, capable of being a strategic export commodity, earning foreign exchange and livelihood for millions of the world's population. The country's foreign exchange earnings from rubber plantations could reach 5.27 billion US dollars. Rubber plantations are a sustainable proposition. This is because rubber plantations as a single plant is a long-lasting system so the price remains profitable and marketing practices are transparent and effective. he economic value per hectare of smallholder rubber plantation uses cost benefit anaysis in West Garo Hills District of Meghalaya region, India for Rs 55014,1. (Goswami \& Challa, 2007). The net benefits of large-scale rubber plantations in Cambodia over a 25 -year period are estimated at USD 15,690 and USD 71,611 for smallholder rubber plantations (Dararath et al, 2011).

Rubber plants as forest plants, can be effective as the lungs of the world and $\mathrm{CO} 2$ inhibitors. Rubber plants play a role in absorbing $\mathrm{CO} 2$ because it has a wider canopy and a broad green leaf surface. The forest area as part of the natural environment functions as a carbon assimilator. Rubber plantations have the potential to to sequester carbon in a relatively short period of time and can improve soil physical and chemical properties. Carbon stock South rubber plantations region of the Paraná State, Brazil is 66.8 and $79.3 \mathrm{Mg} \mathrm{C}$ ha -1 for rubber plantations 4 years and 15 years, (Maggiotto et. al, 2014). The rubber plantations can be used as an alternative land use without affecting the storage of clean forest ecosystem C (Liu et. al , 2015).

The activities of forest area transfer for various forestry including mining business activities resulted in the loss of this function. This function can be restored through reclamation activities on ex-mining land. Forests have the value of the benefits of tangible and intangible products and services (not reflected by market prices). Forest disruptions are continuing for the lack of knowledge and understanding of those benefits. Therefore, economic valuation is needed to determine the value of economic benefits from forests quantitatively (Yusuf et al, 2010). Economic valuation is the value of goods and services can be traded, thus providing income. Economic valuations are based on the economic concepts of utility, satisfaction or pleasure gained by individuals or societies (Betani et al., 2016). Research related to the economic valuation of forest areas both within the mining permit and other forestry areas, and the value of carbon has been done by some previous researchers. The results of research Kodir et. al (2017) found the economic value of post-mining integrated space utilization of PT Bukit Asam South Sumatra until the closure of the coal mine in 2043 using benefit and cost anaisis of USD 91.295.530 (1 USD = Rp 13,329). The economic value of carbon in forest areas contained in the Forest Study With Special Purpose (KHDTK) Forest of Diklat Bukit Suligi for 419,787.6 USD or 5,635,648,530 IDR (Betani et al., 2016). The carbon stock of khdtk Senaru is 126.41 tons c / ha, with ground carbon stocks of 83.71 tons c / ha and soil carbon at 42.7 
tons c / ha (Idris et al., 2013). Carbon values are absorbed in former logged-over forests in coal mining PT Bukit Asam, South Sumatera for 22,810,994,971 IDR (Juniah, 2013). The value of carbon uptake in protected forest areas Indominco coal mining is investigated by Sudirman (2011). Economic Value Carbon stored in protected forests amounted to 59,320,710,000 IDR (Yusuf et al, 2010). The average economic value of carbon uptake in the Above Surface Tree (Study Area in Keriling Lake District, Kerinci Regency) forest is 3,720,854 IDR x 106 / year. for forest area of 31,883.4 ha (Agung 2016). the primary forest carbon value of Bukit Munggu in the Coal Mining Business License of 8,263,675,660 IDR per year for the land area of $257 \mathrm{Ha}$ (Rahmaputri (2014).

The economic assessment of carbon values carried out in the previous study is fundamentally the same, which sets it apart from this study is the percentage concept of revegetation used in determining carbon values. The percentage of revegetation used is based on the percentage of growth over the rubber plant during the time horizon of ex-mining land recoveries.

Rubber plantations are environmentally friendly plants. Since it can reduce $\mathrm{CO} 2$ emissions, where the amount of carbon in the rubber plantation area that can be absorbed during one planting cycle ( \pm 21 years) reaches 97.65 tons CO2 / ha (Stevanus Sahuri, 2014). Rubber plants (hevea brasilliensis) as well as other forest plants are able to process $\mathrm{CO} 2$ as a carbon source used for the photosynthesis process, making this plant has a very big role in the economy and the absorption of CO2 (Sahuri, 2016). Carbon stock per hectare of rubber plant with monoculture planting pattern is bigger than intercropping cropping pattern (Suhari, 2016). Carbon stock per hectare of rubber crops with cropping pattern is presented in Table 1.

Table 1. Carbon stock per hectare rubber plant

\begin{tabular}{clc}
\hline Number & \multicolumn{1}{c}{ Cropping Pattern } & C (ton)/hectar \\
\hline 1 & Intercropping & $16,35-19,39$ \\
2 & Monoculture & 23,07 \\
\hline
\end{tabular}

Source: Sahuri, 2016

The indirect benefit (external benefit) calculated in this study is the carbon value. This benefit is derived from the revegetation of former coal mine PT Samantaka Batubara for rubber plantation. Benefits of carbon values resulting from rubber plantations were analyzed using market value analysis. Calculation of carbon value of former coal mine landings of PT Samantaka Batubara for rubber plantations as follows:

1) Carbon stock per hectare of rubber plant with monoculture cropping pattern is 23,07 ton using result of research of Sahuri (2016). This is based on utilization of the former mining land of PT Samantaka Batubara for plantation that use only one type of plant (monoculture), namely rubber plant (hevea brasilliensis).

2) Carbon price per ton of 13.20 USD referring to the price of the Great Research (2016).

3) The present value calculation for 2017 to 2022 period of restoration of former mining land of PT Samantaka uses PV 2017 price (at the time of the research).

4) The interest rates used on the basis of the average rate of Bank of Indonesia in the period of January December 2017 amounted to 4, 45625\% equivalent to $4.6 \%$.

5) The exchange rate used by the middle exchange rate (middle rate) of Bank Indonesia for the period of January - December 2017 amounts to Rp 13,387, - for 1USD.

6) The equation used to determine the carbon value of the former coal mine of PT Samantaka Batubara per annum as follows:

$$
\text { NKkkbt }=\frac{\mathrm{M}-\mathrm{m}}{M} \times(L \times T c) \times P c
$$

Source: Juniah (2017), modification Rahmaputri (2014), and Juniah et.al (2016)

Where:

NKkkbt $=$ Carbon Value of Rubber Plantation in ex mining land (IDR) 


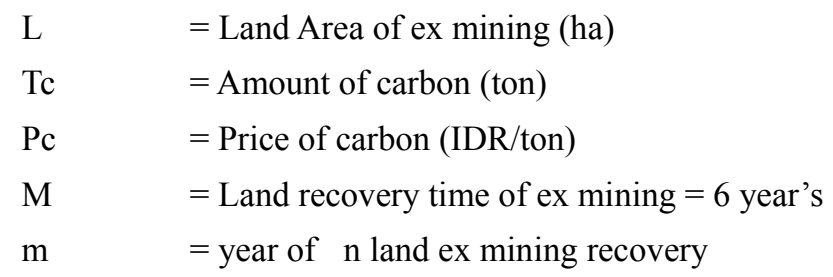

Persentage of rubber plant growth reclamation for the 6 year's recovery time horizon (2017-2022) above, which was used adapted from Juniah et.al, (2016).

7) Determination of the value of carbon benefits of former mining land of PT Samantaka Batubara during the recovery period 2017 to 2022 at PV 2017 prices using the equation below:

$$
\text { NKkktb }-\mathrm{pv}=\sum_{p-1}^{p-q}(\mathrm{NKkkbt}) \times 1 /(1+\mathrm{r}) \mathrm{t}
$$

Source: Juniah (2017), modification Juniah, 2016

Where:

$$
\begin{array}{ll}
\text { NKkkbt-pv } & =\text { Carbon Value of ex mining rubber plantation (Present Value) (IDR) } \\
\mathrm{NKkkbt} & =\text { Carbon Value of ex mining rubber plantation (IDR) } \\
\mathrm{p} & =\text { first year revegetation }=2017 \\
& =1,2,3, \ldots \ldots \mathrm{p}=\mathrm{q} \\
\mathrm{q} & =\text { final year of revegetation }=2022 \\
\mathrm{r} & =\text { interest }(\%) \\
\mathrm{t} & =\text { the length of time the of ex land mining recovered from the beginning of the calculation } \\
& \text { present value (year 2017) }
\end{array}
$$

Based on the calculation, the number of tons of carbon at the location of the former mining area of PT Samantaka Batubara during the 6 year's recovery period from 2017 to 2022 is 6,789 tons. The carbon value is $1,199,649,472$, - IDR or 89,613 USD and the PV carbon value of 2017 of 1,014,329,829, - IDR or 75,770 USD during the Revegetation range from 207 to 2022 on the mining land of PT Samantaka Batubara. The amount of carbon absorbed, carbon values, and PV2017 carbon benefit values over the 2017-2022 range on the former mining land of PT Samantaka Batubara are presented in Table 2.

Table 2. The amount of carbon absorbed, carbon values, and carbon values at PV prices 2017 over the 2017-2022 range on former mining land of PT Samantaka Batubara for rubber plantation

\begin{tabular}{cccc}
\hline Year & $\begin{array}{c}\text { Amount of Carbon } \\
\text { (ton) }\end{array}$ & $\begin{array}{c}\text { Value of Carbon } \\
\text { (IDR) }\end{array}$ & $\begin{array}{c}\text { Benefit Value of Carbon } \\
\text { PV 2017 (IDR) }\end{array}$ \\
\hline 2017 & 0 & 0 & \\
2018 & 399 & 70.567 .616 & 67.464 .260 \\
2019 & 799 & 141.135 .232 & 128.994 .761 \\
2020 & 1.198 & 211.702 .848 & 184.982 .927 \\
2021 & 1.997 & 352.838 .080 & 294.746 .538 \\
2022 & 2.396 & 423.405 .696 & 338.141 .343 \\
\hline Total & 6.789 & 1.199 .649 .472 & 1.014 .329 .829 \\
\hline
\end{tabular}

Based on Table 2 above, it is seen that the utilization of ex-mining land of PT Samantaka Batubara for rubber plant can provide indirect economic benefits (external benefits) for the ecological sustainability of the coal mining environment in the form of carbon value of 1,014,329,829, - IDR or 75,770 USD. Thus the sustainability of the ecological environment can provide benefits for the maintenance of environmental functions as carbon assimilators. This is understandable because the rubber plant as a forest plant can be effective as the lungs of the world, $\mathrm{CO} 2$ inhibitor, very important to absorb $\mathrm{CO} 2$ because it has a wider canopy and broad green leaf surface. Other benefits obtained after coal post mining of PT Samantaka Batubara for rubber plantations as follows: 
a. The direct sustainable economic benefits, especially after the coal post-mining. These benefits will be derived from the sale of rubber crops as a strategic export commodity, earning foreign exchange and livelihoods for millions of the world's inhabitants (Togi \& Sahuri, 2014). Sales of coal as a direct benefit lost due to the end of coal production activities can be replaced. This is because the benefits of coal sales are only limited during the life of the mine.

b. Social benefits will be obtained through the absorption of labor in rubber plantation companies, especially for people living around the mining environment of PT Samantaka Batubara. Thus during the recovery period and after the closure of the mine the social sustainability is maintained.

c. The allotment of former coal mining of PT Samantaka Batubara for rubber plantations after coal post mining can provide an aesthetic value for the mining environment. It is obtained through a wider canopy and a wide green leaf surface provides its own aesthetic beauty and value. Thus the function of the environment as an aesthetic value can be maintained.

d. The existence of rubber plantation in the former coal mine of PT Samantaka Batubara as a forest plant becomes one of the renewable resources that can restore the function of the environment as a provider of raw materials (natural resources).

\section{Conclusion}

The carbon value of former mining land allotment of PT Samantaka Batubara for rubber plantations provides benefits to the mining environment in a sustainable manner, as well as the preservation of environmental functions as a provider of raw materials (natural resources), as carbon assimilators, and as aesthetic value. The carbon value obtained through the revegetation of former coal mining land of PT Samantaka Batubara provides external benefits to the ecological environment in the form of indirect economic benefits worth 1,014,329,829, IDR or 75,770 USD. Carbon stocks contained in rubber plants and carbon sequestration by rubber plants provide ecological benefits for sustaining environmental functions as carbon assimilators. Rubber plants that are characterized by broader canopies and broad green leaf surfaces provide the benefits of preserving environmental functions as an aesthetic giver. The existence of rubber crops as a renewable resource on former coal mines replacing the availability of coal as a non-renewable resource can safeguard environmental functions as a provider of raw materials (natural resources).

\section{Acknowledgment}

Thanks to the management of PT Samantaka Batubara for the opportunity given to the author to conduct a research survey on the location of coal mining business license PT Samantaka Batubara.

\section{References}

Agung, R, P. (2016). Economic Valuation On Tree Above Surface (Study Area in Kecamatan Keliling Lake, Kerinci Regency). Theses Environmental Science Program University of Indonesia.

Betani, A., \& Evi, S. M. (2016). Economic Carbon Valuation in The Stands Level Poles and Trees at Forest for Special Purpose Jungle Training Suligi Mount at Rokan Hulu Regency. Jom Faperta UR (Vol 3 No 2 Oktober 2016).

Coal Mining Company PT Samantaka Batubara. (2017). Post-Mining Plan Report and PT Samantaka Batubara Reclamation Plan.

Coal Mining Company PT Samantaka Batubara. (2011). Environmental Impact Analysis and Feasibility Study of PT Samantaka Batubara.

Coal Mining Company PT Adaro Indonesia. (2012). PT Adaro Indonesia Mining Closure Plan PT Samantaka Batubara.

Coal Mining Company PT Kaltim Prima Coal. (2016). Sustainability Report, Kaltim Prima Coal - Welcome.

Dallaire, K., Skousen, J., \& Schuler, J. (2015). Height of Three Hardwood Species Growing On Mine Sites Reclaimed Using the Forestry Reclamation Approach Compared to Natural Conditions. Journal American Society of Mining and Reclamation, 4(2), 20-35. https://doi.org/10.21000/JASMR15020020

Daru, T. P., \& Pagora, H. S. (2016). Utilization of Coal Post Mining Land as Sustainable Cattle Farming. Ziraa'ah, 41(3), 382-392.

Dariah, A., Abdurachman, A., \& Subardja, D. (2010). Reclamation of Ex-Mining Land for Agricultural Extensification. Journal of Land Resources, 4(1). 
Dararath, Y., Neth Top, N., \& Lic, V. (2011). Rubber Plantation Development in Cambodia: At What Cost? Retrieved from https://surumer.uni-hohenheim.de/fileadmin/einrichtungen/surumer/Rubber_Plantation_Development_in_C ambodia.pdf

Hidayanto, M., Yossita, F., \& Chary Septyadi, M. (2014). Optimalization of Used Coal Mining for Rice Development in East Kalimantan. Proceedings of the National Seminar on "Specific Agricultural Technology Innovation Location". Banjarbaru 6-7 August 2014.

Idris, M. et al. (2013). Studies of vegetation and carbon stocks in forest areas with special purpose (khdtk) Senaru, Bayan North Lombok. Journal of Forestry Science, VII(1).

Juniah, R., Dalimi, R., Suparmoko, M., \& Moersidik, S. S. (2013). Public Health Impact of Coal Mining Among Community Living in Coal Mining Area (Review on Environmental Benefits to Absorb Carbon). Journal of Health Ecology, 12(1), 252-258.

Juniah, R. (2013). Environmental Sustainability Model of Coal Mining Study Value of Environmental Services, And Water Void Mine For Raw Water In PT Bukit Asam Tbk Tanjung Enim South Sumatra. Dissertation. Environmental Science Program University of Indonesia. Jakarta.

Juniah, R., Dalimi, R., Suparmoko, M., Moersidik, S. S., \& Waristian, H. (2016). Environmental Value Losses as Impacts of Natural Resources Utilization of in Coal Open Mining. Matec Proceding Scopus Index.

Juniah, R. (2017). Suistanable Mining Environment: Technical Review of Post Mining Plans. Indonesian Journal of Environtmental Management and Susitanability, 1(1).

Kokko, K., Buanes, A., Koivurova, T., Masloboev, V., \& Pettersson, M. (2015). Sustainable Mining, Local Communities and Environmental Regulation. Barents Studies: Peoples, Economies and Politics, 2(1), 50-81.

Kodir, A., Hartono, M., Haeruman, J., \& Mansur, I. (2017). Integrated post mining landscape for suistanable land use: acase atudy in south sumatera, Indonesia. Suistanable environment research, 27(4), 203-213. https://doi.org/10.1016/j.serj.2017.03.003

Kusmana, C., Setiadi, Y., \& Al-Anshary, M. A. L. (2013). Study of Plant Growth as a Result of Revegetation in Coal Ex-Mined Land PT. Arutmin Indonesia Site Batulicin South Kalimantan. Journal of Tropical Silviculture, 4(3), 160-165.

Liu, C. et al. (2017). Carbon Stocks across a Fifty Year Chronosequence of Rubber Plantations in Tropical China. Forests, 8(6), 209. https://doi.org/10.3390/f8060209

Maggiotto, S. et al. (2014). Potential carbon sequestration in rubber tree plantations in the northwestern region of the Paraná State, Brazil. Maringá, 36(2), 239-245. https://doi.org/10.4025/actasciagron.v36i2.17404

Margarettha. (2010). The Use of Ex-Coal Mining Soil with Mycorrhiza Biofertillizers to Growth Sweet Cron. $J$. Hydrolitan, 1(3), 1-10.

Mashud, N., \& Manaroinsong, E. (2014). Utilization of Coal Mine for Sago Development. Journal of Palma, 15(1), 56-63.

Ministry of Energy and Mineral Resources of the Republic of Indonesia. (2009). Regulation No. 4 of 2009 on Mineral and Coal Mining. Jakarta.

Ministry of Energy and Mineral Resources of the Republic of Indonesia. (2014). Ministerial Regulation no. 7 years 2014 Reclamation Plan and Post-Mining Plan. Jakarta.

Ministry of Energy and Mineral Resources of the Republic of Indonesia. (2010). Government Regulation no. 78 of 2010 About Reclamation and Closure of Mining. Jakarta.

Ministry of Energy and Mineral Resources of the Republic of Indonesia. (2014). Ministerial Regulation no. 7 years 2014 Reclamation Plan and Post-Mining Plan. Jakarta.

Ministry of Environment of the Republic of Indonesia. (2009). Law Number 32 Year 2009 on Environmental Protection and Management. Jakarta.

Ministry of Environment of the Republic of Indonesia. (2009). Law Number 32 Year 2009 on Environmental Protection and Management. Jakarta.

Ministry of Environment and Forestry of the Republic of Indonesia. (2017). Government Regulation No. 46 of 2017 on Environmental Instruments. Jakarta. 
Rahmaputri, E. S. (2014). Cost Analysis and Economic Benefits of Conversion of Forest Areas Becoming Coal Mining (Case Study: WIUP PTBA Bukit Munggu, Tanjung Enim Sub-District, Muara Enim District, South Sumatera Province). Department of Economic Resources and Environment Faculty of Economics and Management Bogor Agricultural University.

Scagline, S., Skousen, J., \& Griggs, T. (2015). Switchgrass and Miscanthus Yields On Reclaimed Surface Mines for Bioenergy Production. Journal American Society of Mining and Reclamation, 4(2), 20-35. https://doi.org/10.21000/JASMR15020080

Sahuri. (2016). The Potency of Carbon Absorption on Rubber of Intercropping Patternof Forest Plant. Journal of Tropical Forests, 4(3).

Syafrianto, M. K. (2016). Coal Mining Field in South Kalimantan Province as Plantation Land.

Sudirman, D. (2011). Optimization of Environmental Damage Compensation Coal Mining Activities in Protection Forest. Doctoral dissertation. Environmental Science Program University of Indonesia.

Togi, S. C., \& Sahuri. (2014). The Potency of Increase in Carbon Sequestration Level in Sembawa Rubber Plantation, South Sumatra. Widyariset, 17(3), 363-372.

Tamin, R. P. (2016). Semai Jabon Growth (Anthocephalus Cadamba Roxb Miq.). On Enriched Coal Enriched Media Fungi Arbuskula Mycorrhiza, Coal Waste and Fertilizer Npk. Journal of Research Universitas Jambi Science Series, 18(1), 33-43.

Yuniawatiningtyas, E. (2014). Landscape Planning Former Coal Mine for Arboretum In White Soil Area Sebuku Island South Kalimantan. Essay. Department of Landscape Architecture Faculty of Agriculture Bogor Agricultural University.

Yusuf, S. S., Astuti, R., \& Sugiyanto, D. (2010). Value of Forest Occurred Lost When the Changes Function Protection Forest. Agritek, 18(1).

\section{Copyrights}

Copyright for this article is retained by the author(s), with first publication rights granted to the journal.

This is an open-access article distributed under the terms and conditions of the Creative Commons Attribution license (http://creativecommons.org/licenses/by/4.0/). 